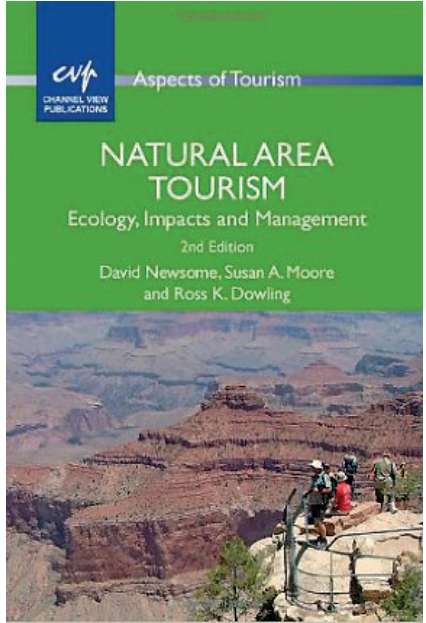

Terms like nature-based tourism, adventure tourism, ecotourism and sustainable tourism denote forms and approaches of tourism which are often kept apart from mainstream tourism. The kind of term like Natural Area Tourism was characterized by David Newsome, Susan A. Moore und Ross K. Dowling in their standard reference International Year of Ecotourism 2002. This publication has since been revised and published by Newsome and Moore (from Murdoch University, Western Australia) and Dowling (Cowan University, Western Australia).

The book focuses on natural landscapes and parks, visitor management and management of protected areas. It is strongly oriented on planning and practice and has the character of a textbook. There is no new information, but the description of the tradition of various visitor planning frameworks mainly practised in Australia and North America is important.

The authors are concerned to give an overall perspective on natural area tourism and related forms in their introduction. Various definitions are aligned and compared. Natural area tourism has been understood as tourism practised in natural areas. Natural areas are seen by the authors "as regions that have not been significantly altered by bumankind. Such areas contrast with areas that have significant human imprint on the natural environment through past and/ or present use." After the introduction the book is divided into six subject-related chapters, followed by a conclusion, as detailed below.

In the chapter The Ecological Perspective, the authors give an overview about relevant ecosystems for tourism, such as coral reef ecosystems, tropical rain forest, African savannah, semi-natural ecosystems, etc. A true philosophy of ecosystems tourism will be developed. The chapter Environmental Impacts focuses on the sources of touristic impacts on nature, such as trampling, access roads and trails, built facilities / campgrounds or the use of water edges.

The chapter Visitor Planning describes the reasons for planning, gives the most important definitions and explains the importance of stakeholder involvement in visitor planning. The reason why the concept of carrying capacity has failed and why the approach of ac-
Newsome, D., S.A. Moore \& R.K. Dowling

\section{Natural Area Tourism Ecology, Impacts and Management}

\author{
Channel View Publications. Bristol/Buffalo/ \\ Toronto ( $2^{\text {nd }}$ edition 2013).
}

ISBN: 978-1-845413-81-1

ceptable change is more focused is also explained. Still a very useful part of the book is the description of important recreation/tourism planning frameworks (Recreation Opportunity Spectrum ROS, Limits of Acceptable Change LAC, Visitor Impact Management VIM, Tourism Optimation Management Model TOMM etc.).

However, the planning frameworks were mostly theoretical and have sometimes not been implemented. Often they are also too specific to be applied in the management plans of national parks. Another reason is the lack of human and financial resources. In addition, there is more confusion about different approaches in practice.

Concrete strategies, projects and examples of natural area tourism are demonstrated in the chapter Management Strategies and Actions. The emphasis here is on planning and implementation of nature-based tourism activities, mainly in protected areas, and on managing the tourism industry. Examples with a regional focus are Australia and North America.

The chapter Interpretation for Nature Tourism contains interpretation as a key component of visitor management and satisfaction. The focus is on actual methods of environmental education, including tour guides as a role model and electronic educational resources. The chapter Monitoring explains the principles of monitoring and describes the state of the art in this field. Current approaches of visitor monitoring with examples of practices are documented. A comprehensive list of literature rounds the book off.

This publication as standard reference contains various important indications and information for those who are not familiar with the situation in Australia and North America. Some of the presented strategies and applications are also applicable in Europe and the Alps, if only with adaptations. The definition of natural area tourism, which here is essentially oriented on natural landscape, should therefore be extended to include the nature-based cultural landscape types of Europe.

Dominik Siegrist, Rapperswil (Switzerland) 